\section{Koraljka Vlajo}

Muzej za umjetnost i obrt Museum of Arts and Crafts

Trg Republike Hrvatske 10 Zagreb, Hrvatska

koraljka.vlajo@muo.hr

(iD) orcid.org/0000-0003-4908-0112

Izvorni znanstveni rad Original scientific paper

UDK / UDC:

7.05:615(497.5)"1956/1990"

7.05 Vulpe, $M$.

DOI:

10.17685/Peristil.63.12

Primljeno / Received:

16. 10. 2020.

Prihvaćeno / Accepted:

22. 12. 2020.

\section{Vizualni kodovi Milana Vulpea: retorika Plivinih reklama od 1956. do 1990.}

\author{
Milan Vulpe's Visual Codes: the Rhetoric of \\ Pliva's Advertisements from 1956 to 1990
}

\begin{abstract}
APSTRAKT
U članku se po prvi put kritičko-analitičkom metodom vizualne retorike analiziraju radovi i vizualne taktike $u$ formiranju reklamnih poruka o svrsi i djelovanju Plivinih proizvoda jednog od najznačajnijih hrvatskih dizajnera, Milana Vulpea. Rad se temelji na istraživanju sačuvanih reklamnih materijala (brošura, deplijana, oglasa) za Tvornicu farmaceutskih i kemijskih proizvoda Pliva koji su od 2014. godine postali dio fundusa Zbirke grafičkog dizajna Muzeja za umjetnost i obrt. Posebna se pozornost posvećuje načinu na koji Vulpe kroz metodički pristup dizajnu vizualnih komunikacija sustavno gradi odnos s Plivinom ciljanom publikom.
\end{abstract}

\section{KLJUČNE RIJEČI}

farmaceutska industrija, grafički dizajn, Milan Vulpe, Pliva, reklama, vizualna retorika

\begin{abstract}
For the first time, the article analyzes works and visual tactics in the formation of advertising messages about the purpose and operation of Pliva's products of one of the most important Croatian designers, Milan Vulpe. The work is based on the research of preserved advertising materials (brochures, leaflets, advertisements) for the Pliva pharmaceutical and chemical products factory, which since 2014 have become part of the Museum of Arts and Crafts' graphic design collection. Special attention is paid to the way Vulpe systematically builds a relationship with Pliva's target audience through a methodical approach to visual communication design.
\end{abstract}

\section{KEYWORDS}

pharmaceutical industry, graphic design, Milan Vulpe, Pliva, advertising, visual rhetoric 
Milan Vulpe (Dubrovnik, 1918. - Zagreb, 1990.) jedan je od najznačajnijih hrvatskih grafičkih dizajnera koji je većinu svog dizajnerskog opusa ostvario u području reklamnog dizajna. Tijekom svojeg radnog vijeka, bilo samostalno ili posredstvom velikih oglašivačkih agencija Ozeha i Interpublic, suradivao je s brojnim domaćim tvrtkama (Chromos, Pliva, TOZ, Saponia, Karbon), institucijama (Leksikografski zavod Miroslav Krleža), te kulturnim i gospodarskim manifestacijama $(\mathrm{Mu}-$ zički biennale, Zagrebački velesajam). Vulpeov angažman za Tvornicu farmaceutskih i kemijskih proizvoda Pliva trajao je od 1956. do 1990. godine, a tijekom te suradnje dizajnirao je, uz brojne druge elemente vizualnih komunikacija, i oko tisuću promotivnih letaka, deplijana i brošura za Plivine lijekove i preparate. ${ }^{1}$ Riječ je o angažmanu koji je potrajao punih 35 godina, unutar kojega je Vulpe osmislio različite vizualne taktike i tehnike komuniciranja često kompleksnih poruka o namjeni i sadržaju Plivinih proizvoda. Iako se Vulpeov estetski izričaj mijenjao tijekom godina, bez sumnje se može ustvrditi da je sustavno razvijao prepoznatljive vizualne kodove u prenošenju značenja čitateljima Plivinih promotivnih materijala. U članku se na osnovi sačuvanih radova i arhivske dokumentacije analiziraju Vulpeove taktike u komuniciranju Plivinih lijekova kroz vizuru vizualne retorike kao analitičke metode fokusirane na vizualne postupke uvjeravanja. Kroz primjenu postulata klasičnih retoričkih kanona analizira se Plivina reklamna djelatnost i progresivni Vulpeovi i Plivini napori u sustavnoj izgradnji odnosa s ciljanom publikom.

\section{Vizualna retorika i dizajn}

Vizualna retorika je kritičko-analitički alat za obradu vizualnih informacija usmjeren na komunikacijski aspekt slika, posebice na njihovu funkciju uvjeravanja - bilo da je riječ o bazičnoj razini uvjeravanja u kvalitetu nekog proizvoda, bilo da je riječ o prikrivenom, čak i nesvjesno ugrađenom zastupanju prevladavajuće ideologije. Fokus vizualne retorike na vizualne postupke uvjeravanja čini je više no prigodnom metodom analize Vulpeovih promotivnih materijala za Plivu. Uostalom, iako je vizualna retorika metoda koja se danas koristi za analizu čitavog spektra vizualnih fenomena - od arhitektonskih djela do ručnog rada - Roland Barthes inaugurirao je pojam retorika slike ${ }^{2}$ upravo kroz analizu oglasa (za tjesteninu). Gotovo istovremeno, 1965. godine, tragajući za alatima za sustavnu analizu grafičkog dizajna (posebice onog dijela dizajna posvećenog oglašavanju) Gui Bonsiepe ${ }^{3}$ okrenuo se vizualnoj retorici osmišljavajući vlastiti sustav za analizu „uvjeravačke strukture” oglašavanja. Bonsiepeovim putem analize retoričkih figura osamdesetih nastavljaju Hanno Ehses i Charles Kostelnick u svojim ranijim radovima. Interes za vizualnu retoriku posebno se intenzivirao tijekom posljednjih dvadesetak godina, a brojni se teoretičari bave upravo njezinom bliskošću s disciplinom dizajna (posebice dizajna vizualnih komunikacija), medu inima Leslie Atzmon, Richard Buchanan, Gesche Joost, Jens E. Kjeldsen, Charles Kostelnick, Barbara J. Phillips, Sharon Helmer Poggenpohl. U Hrvatskoj se ovim područjem još uvijek bavi malen broj znanstvenika. Međutim, Gabrijela Kišiček ${ }^{4}$ daje jasan i jezgrovit pregled suvremenih saznanja i dvojbi u području vizualne retorike, a pod njezinim mentorstvom izrađeno je i više diplomskih radova koji doprinose poznavanju i popularizaciji vizualne retorike u Hrvatskoj. Većina se tih rado$\mathrm{va}^{5}$ bavi upravo retoričkom analizom jednog vida dizajnerske aktivnosti tj. oglašavanja.

Posebno je u tom smislu zanimljiva analiza G. Mauricija Mejíae ${ }^{6}$ koji je uspostavio paralele izmedu disciplina retorike i dizajna na strukturalnoj razini, uspoređujući elemente retoričkog i dizajnerskog komunikacijskog procesa (govornik/ dizajner - kanoni/proces dizajna - govor/objekt dizajna - publika/korisnik). Retoričke analize dizajnerske produkcije izuzetno su širokog spektra tema, od Bonsiepeovih i Ehsesovih paralela izmedu verbalnih i vizualnih stilskih figura, ${ }^{7}$ te Kjeldsenovih i Buchananovih studija primjene klasičnih retoričkih apela ${ }^{8}$ do dubljih analiza uloge publike u retoričkom videnju komunikacijskog procesa. Ostvarivanje ciljane komunikacije s odabranom publikom bazična je karakteristika dizajna, a takva „namjerna i promišljena proizvodnja značenja" 9 čini dizajn retoričkim procesom. Mejía, Kostelnick, Kjeldsen i drugi dodatno razrađuju ovu temu naglašavajući važnost funkcionalne pismenost $i^{10}$ (sposobnost pojedinaca za interakciju unutar određene društvene formacije), odnosno pripadnosti kulturnom krugu koji omogućava dekodiranje pojedincu namijenjenih simboličkih poruka.

\section{Definiranje Plivine publike}

U tom smislu, retoričku analizu Vulpeovih radova za Plivu vrijedi započeti upravo iz ovog smjera 
- pobližim odredivanjem publike Plivinih promotivnih materijala. U jedinom katalogu posvećenom Vulpeovom stvaralaštvu, onome izdanom povodom izložbe u Muzeju za umjetnost i obrt 1977. godine, Lada Kavurić egzaktno je uočila Vulpeovu spretnost prilagodbe Plivinoj publici: „Potrošači su proizvoda farmaceutske industrije široke mase, ali, kako je njihova mogućnost izbora i opredjeljenja za pojedini proizvod tako minimalna da se može zanemariti, s obzirom na specifičnost proizvoda, cjelokupna ekonomskopropagandna grafika namijenjena je stručno obrazovanom kadru farmaceuta i liječnika. Oni su ta publika koju treba upoznati s novim preparatima, njihovim svojstvima i namjenom. S jedne strane, mogli bismo reći, komorni dijalog dvaju donekle izjednačenih sugovornika, grafičkog dizajnera i stručnjaka po profesiji, rezultirao je veoma dobrim, često rafiniranim likovnim rješenjima. (...)" ${ }^{11}$

Medutim, u spomenutom „komornom dijalogu” zanemarena je uloga jednog od sugovornika: klijenta, farmaceutske industrije, čije poruke Vulpe spretno prenosi. Naime, u ovom komunikacijskom procesu nije riječ tek o intuitivnom pronalasku zajedničkog jezika između talentiranog dizajnera i liječničke profesije, već o promišljenom i izgrađenom pristupu specifičnoj Plivinoj publici, osmišljenom na osnovi tada prihvaćenih postulata ekonomske propagande. Pliva svoje korijene vuče iz Tvornice kemijsko-farmaceutskih proizvoda Kaštel d.d. ${ }^{12}$ koja je od početka tridesetih godina prošlog stoljeća intenzivno surađivala na oglašavanju svojih proizvoda s umjetnikom i dizajnerom Pavlom Gavranićem. Suradnja s Gavranićem nastavlja se i u doba Plive (do pedesetih godina dvadesetog stoljeća), ${ }^{13}$ te je u tvrtki, unatoč turbulencijama rata i novog društvenog sustava, očito zadržan kontinuitet u promišljanju marketinških aktivnosti. Aktivna oglašivačka scena 1930-ih, koja se ponovo uspostavlja u socijalističkoj Jugoslaviji početkom pedesetih godina, utemeljena je na stručnim radovima, raspravama i aktivnostima niza teoretičara (često istovremeno i praktičara) ekonomske propagande poput Čede Dintera, Dušana Mrvoša, Fedora Rocce i Josipa Sudara. Prva domaća poslijeratna oglašivačka agencija Ozeha ${ }^{14}$ već je od 1954. godine izdavala svoj časopis Naš publicitet, a već krajem pedesetih u Zagrebu su - godinu za godinom - izdana dva opširna priručnika o ekonomskoj propagandi: Sudarova Ekonomska propaganda u teoriji i praksi' ${ }^{15}$ (1958.) i Mrvoševa Propaganda reklama publicitet: teorija i praksa ${ }^{16}$ (1959.) u izdanju agencije Ozeha. I u Sudarovom i u Mrvoševom priručniku Vulpeovi radovi za Chromos i Plivu već su prepoznati i reproducirani kao primjeri dobre domaće prakse. ${ }^{17}$ Teoretičari i propagandisti unutar agencija Ozeha i Interpublic ${ }^{18}$ s kojima je Vulpe intenzivno suradivao od kraja $1940-$ ih $^{19}$ bili su itekako svjesni važnosti prilagodbe ,jezika propagande” reklamiranom proizvodu i ciljanoj publici. ${ }^{20}$ Zato Vulpeov dizajn, kako za Chromos, tako i za Plivu, ne treba promatrati isključivo kao napore „herojskog” umjetnika (u ovom slučaju, dizajnera) koji je vrhunski dizajn za domaću industriju stvarao instinktivno i sustavu unatoč, već i u svjetlu tadašnjih teorijskih saznanja o ekonomskoj propagandi. Ključ čitanja Vulpeovih rješenja za Plivu upravo je u detektiranju pokušaja stvaranja spona profesionalne bliskosti i razumijevanja između stručnjaka - farmaceutske industrije i liječnika - koji se nalaze na istom zadatku liječenja bolesti. Vulpeovi vizualni kodovi koji ne prežu ni od crnog humora (toliko čestog u privatnim liječničkim razgovorima) služe izdvajanju struke od laika koji, u ovom slučaju, gotovo da preuzimaju ulogu „drugog”. Uostalom, kolektivni se identitet (struke) i gradi naspram neophodnih drugih koji su iz tog kolektiviteta isključeni. ${ }^{21}$ Stručna Vulpeova (Plivina) publika i dodatno je diferencirana: većinom je muškog roda. Prema podacima Zavoda za statistiku u Hrvatskoj 1960. godine od ukupnoga broja liječnika bilo je samo 29,5 \% žena, a postotak liječnica do 1976. godine tek se neznatno povećao na $36,5 \% .{ }^{22}$ Dakle, Plivine klijente tijekom većine Vulpeovog angažmana činila je prvenstveno muška visokoobrazovana društvena elita.

Svijest Plivinih propagandista i samog Milana Vulpea o specifičnosti Plivine publike uočljiva je već analizom razvoja promotivnih materijala koje je Vulpe radio za Plivu tijekom prvih godina suradnje (1956. - 1958.). Početak Vulpeove suradnje s Plivom karakterizira vizualni leksik sličan onom kojeg je upražnjavao za potrebe Chromosa tih godina, jednostavan, karikaturalni crtež i empatičan ton, te slogan koji se obraća izravno korisniku (bolesniku), primjeren korespondenciji sa širom javnosti (Plivadon). Međutim, već od 1958., usporedno sa sve češćim narudžbama za oglašavanje receptnih lijekova (antibiotik Geomycin), mijenja se i Vulpeov izričaj: odbacuje se prikaz pacijenata, a u prvi plan postavlja racionalno objašnjenje djelovanja lijeka kroz anatomske 


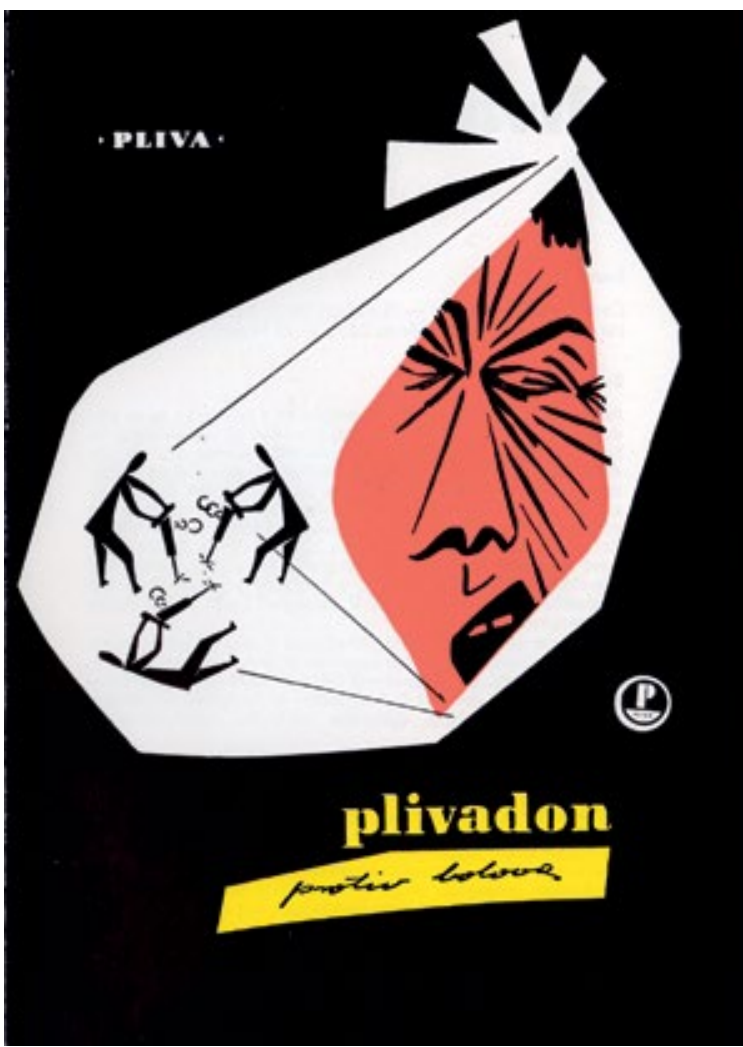

1 Milan Vulpe, deplijani za lijek protiv bolova Plivadon, 1957. i antibiotik Geomycin, 1958., Muzej za umjetnost i obrt, Zbirka grafičkog dizajna, Zagreb (dalje: MUO)

Milan Vulpe, leaflets for painkiller Plivadon, 1957, and antibiotic Geomycin, 1958, Museum of Arts and Crafts, Graphic Design Collection, Zagreb (MUO)

dijagrame i kemijske formule (sl. 1). ${ }^{23}$ Da je riječ o promišljenoj promjeni pristupa oglašavanju, govori i istovremeni redizajn Plivinog znaka ${ }^{24}$ čije se linije osuvremenjuju, dodatno pojednostavljuju i učvršćuju (sl. 2), te promjene stila verbalne komunikacije u objašnjenjima djelovanja lijeka koja tih godina preuzima danas uobičajenu formu strogo impersonalnog obraćanja. ${ }^{25}$

Ako ovo zapažanje pretočimo u govor vizualne retorike, možemo reći da su Vulpeovi promotivni radovi Plivinu primarnu publiku (liječnike) uvjeravali korištenjem sva tri retorička apela (logos, ethos, pathos). Ovi klasični (Aristotelovi) retorički apeli načini su persuazije koji djeluju različitim taktikama apeliranja na publiku: kroz logičko rasuđivanje (logos), karakter i etičnost govorni$\mathrm{ka}$ (ethos), te emotivno stanje publike (pathos). ${ }^{26}$ Logos apelira na razum te se kroz ovaj model uvjeravanja publici podastiru dokazi i činjenice, a od

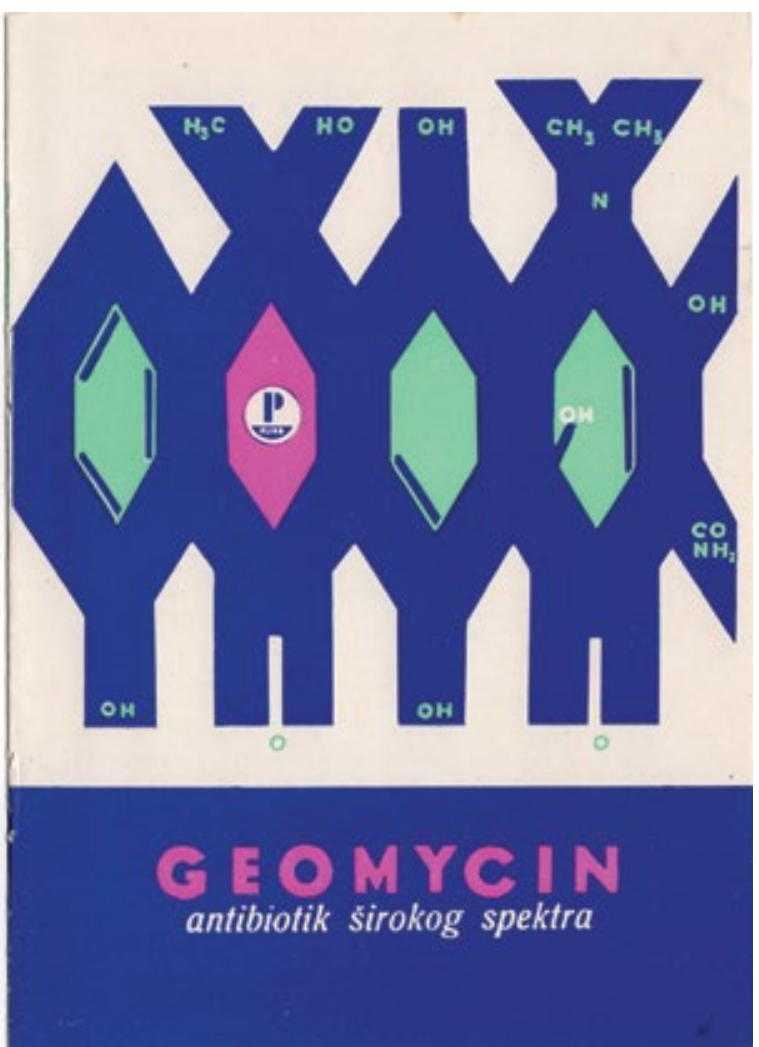

2 Znakovi tvornice Pliva iz 1956. i 1958. godine

Signs of the Pliva factory in 1956 and 1958
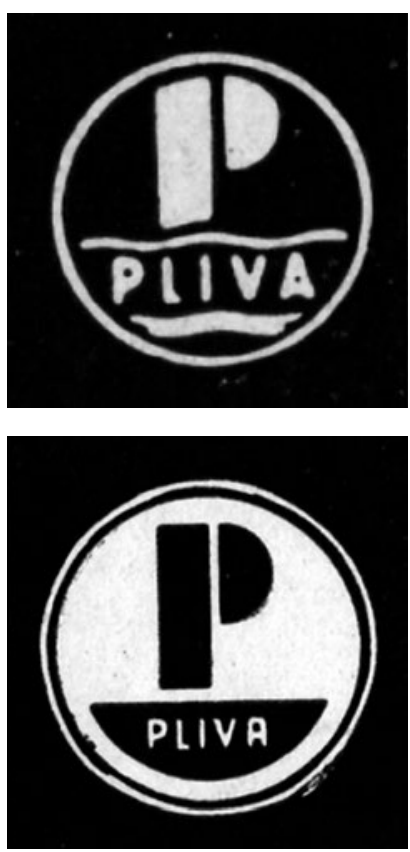


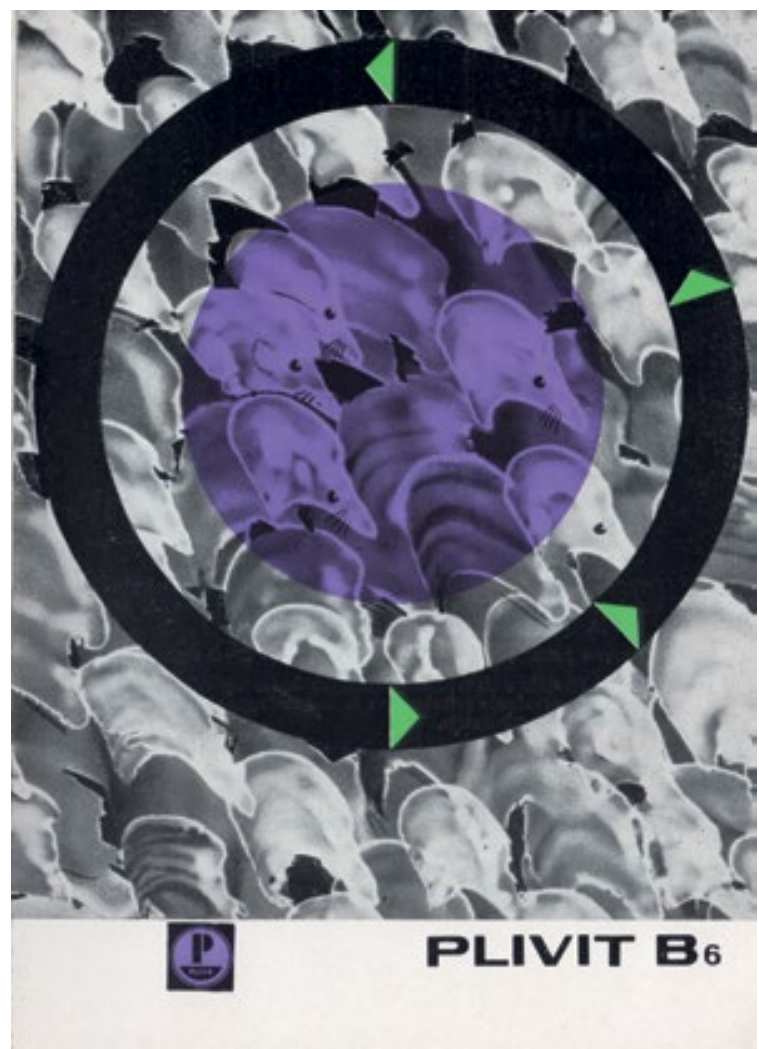

publike se očekuje njihovo objektivno sagledavanje i logičko, konzistentno zaključivanje. ${ }^{27}$ Ethos se poziva na karakter, autoritet, vjerodostojnost, pa i popularnost govornika - publika će riječi takvih govornika prihvatiti zbog naklonosti prema njima. ${ }^{28}$ Unutar vizualne retorike Kjeldsen treću vrstu apela, pathos, definira kao figurativne reprezentacije kojima je cilj pobuditi emocije opisane u retoričkoj teoriji. Cilj je ovog pristupa stvaranje emocionalne veze s govornikom, što će doprinijeti tome da publika govornikove stavove i teze shvati osobno. ${ }^{29}$

\section{Retorički govor Plivinih oglasa - pathos}

Vulpeov pathos, čak i kad se koristi taktikama pobuđivanja snažnih emocija, prvenstveno se fokusira na pobudivanje „dobrih” emocija kroz duhovitu metaforičnu interpretaciju bolesti ili djelovanja lijeka. Vulpe sebi može povremeno

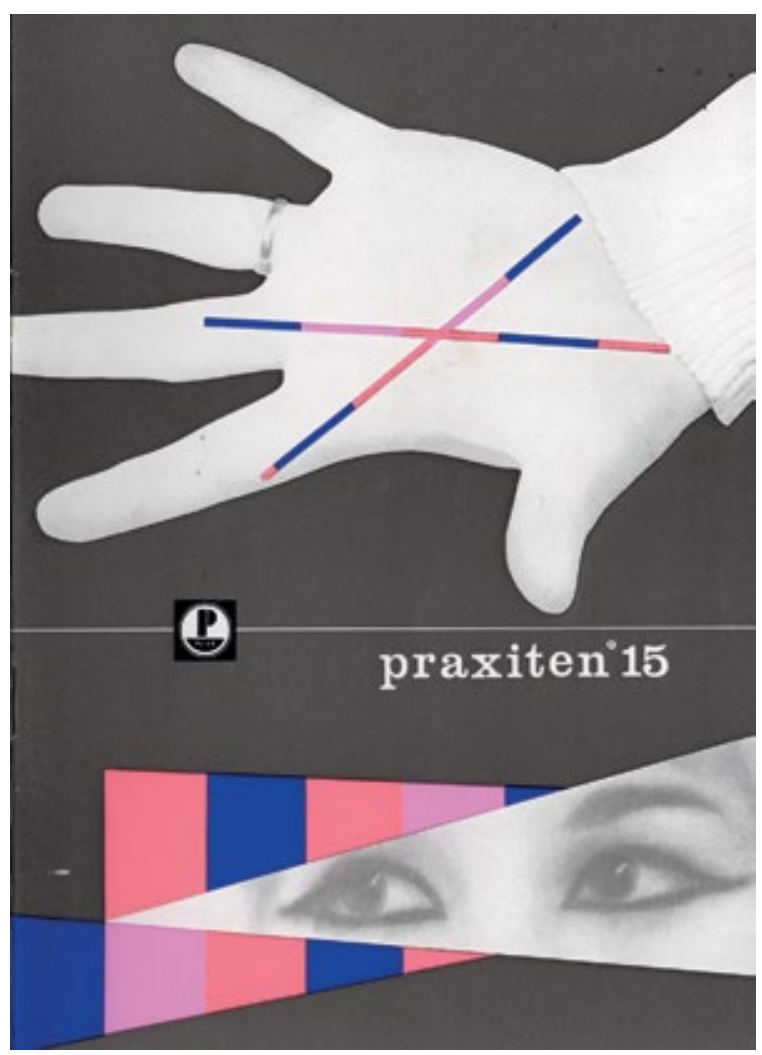

dopustiti dosjetke koje se podsmjehuju pacijentu (kao u slučaju lijeka protiv alkoholizma Plivit B6 gdje, unutar uglavnom apstrahiranog prikaza, „podvaljuje” i nekoliko bijelih miševa), jer primarni cilj Vulpeovih uradaka nije identifikacija s bolesnikom, već s onim koji bolest liječi, sa stručnjakom (sl. 3). Efikasnost humora u oglašavanju prepoznata je već u prijeratnoj praksi, a Sudar i Mrvoš u svojim priručnicima potvrđuju pozitivnu ulogu humora koji ,proizvodi dobro raspoloženje i naklonost prema proizvodu koji se tako reklamira" ${ }^{30}$ Duhovitost Vulpeovih rješenja zasniva se na neočekivanim metaforama, pomaknutim interpretacijama inače suhoparnih dijagrama i shema, te na nizanju slojeva informacija čije dekodiranje zahtijeva aktivno sudjelovanje i interpretaciju čitatelja. Vulpeov humor bazira se na entimemu - retoričkom silogizmu čija je važna karakteristika sposobnost uvjeravanja publike bez 


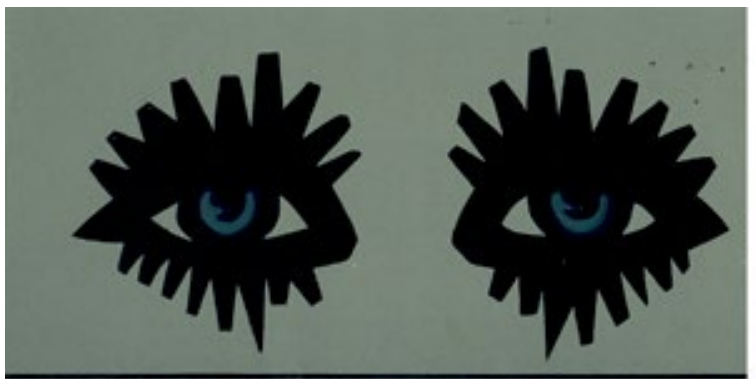

PAREMIN
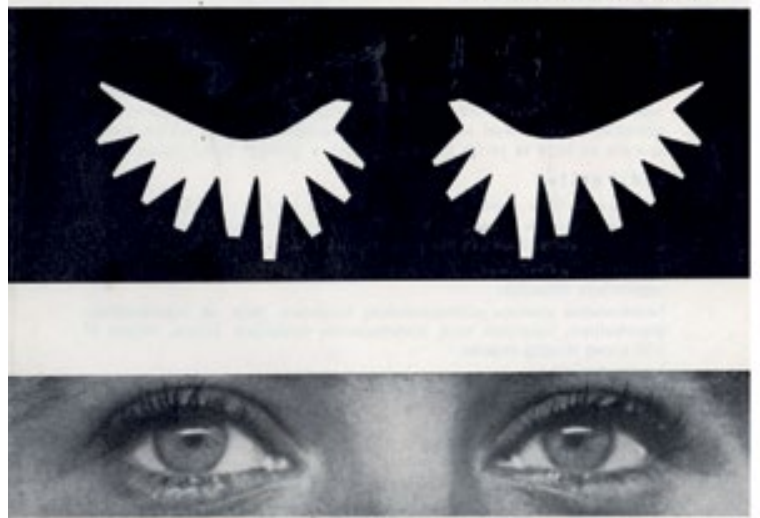

Milan Vulpe, deplijani za sedativ i hipnotik Paremin oko 1966. i antiepileptik Asamid, 1970., MUO

Milan Vulpe, leaflets for sedative and hypnotic Paremin, c.1966 and antiepileptic Asamid, 1970, MUO

potrebe isticanja svih premisa argumenta. „Velik dio uvjeravačke snage entimema nalazi se upravo u premisi koja nedostaje jer se njime poziva publiku da aktivno sudjeluje u dovršavanju argumenta, pomažući tako retoru u stvaranju vjerojatnog znanja čime publika postaje dionikom $\mathrm{u}$ argumentu. (...). Sposobnost nadopunjavanja nedostajuće premise ovisi o postojanju kulturalnog znanja kod publike." ${ }^{11}$ Danas zbunjujuća naslovnica deplijana za sedativ Praxiten 15 (sl. 4) dobar je primjer korištenja entimema: istovremeno i zorno dokazuje da uspješnost retoričkog izričaja ovisi o sposobnosti identifikacije zajedničkih kulturnih kodova, to jest, mogućnostima članova društva da prepoznaju odredene konvencije i kodove zbog toga što dijele kulturne i društvene vrijednosti i norme. Naime, ključ za razumijevanje ovog prikaza leži u prepoznavanju dva mikado štapića na ženskom dlanu. Mikado, igra koja

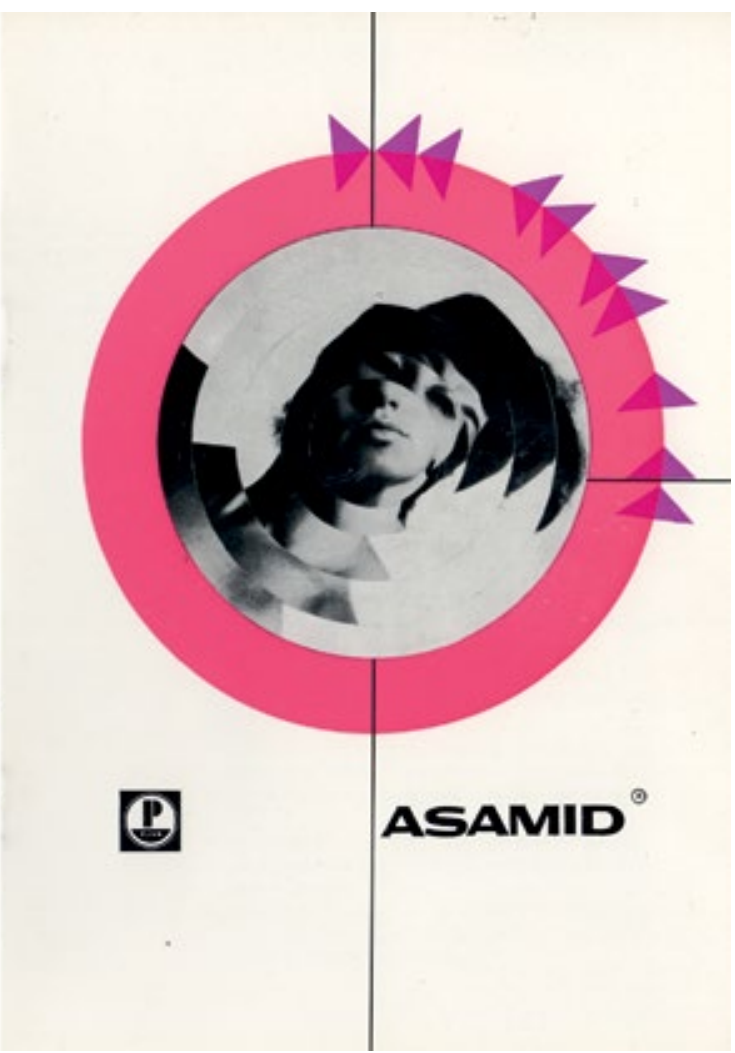

zahtjeva fokus, koncentraciju i izvrsnu motoriku, bila je sastavni dio jugoslavenske svakodnevice šezdesetih i sedamdesetih godina, no današnjoj je publici gotovo nepoznata. Iz kolektivnog sjećanja polako se gube i kotlići s porculanskim, visećim ručkama za povlačenje (lijek za smetnje pri probavi kod djece, Mexaform), i starinske pumpe za vodu (lijek za srčane smetnje, Coramin), te je samo pitanje trenutka kada će i ove metafore većini postati neprepoznatljive. Deplijan za Praxiten 15 prilika je i da se, barem ukratko, spomene specifičan tretman ženskog lika u Plivinim oglasnim materijalima tih godina. Naime, u rijetkim slučajevima prikaza pacijenata na naslovnicama deplijana, uloga bolesnika uglavnom je rezervirana za žene. ${ }^{32}$ Ženski lik posebice se često koristi pri promociji lijekova za glavobolje, psihičke smetnje i neurološke bolesti (poput sedativa Praxitena 15, ${ }^{33}$ Trebarbita, Paremina ili antiepileptika Asamida). 


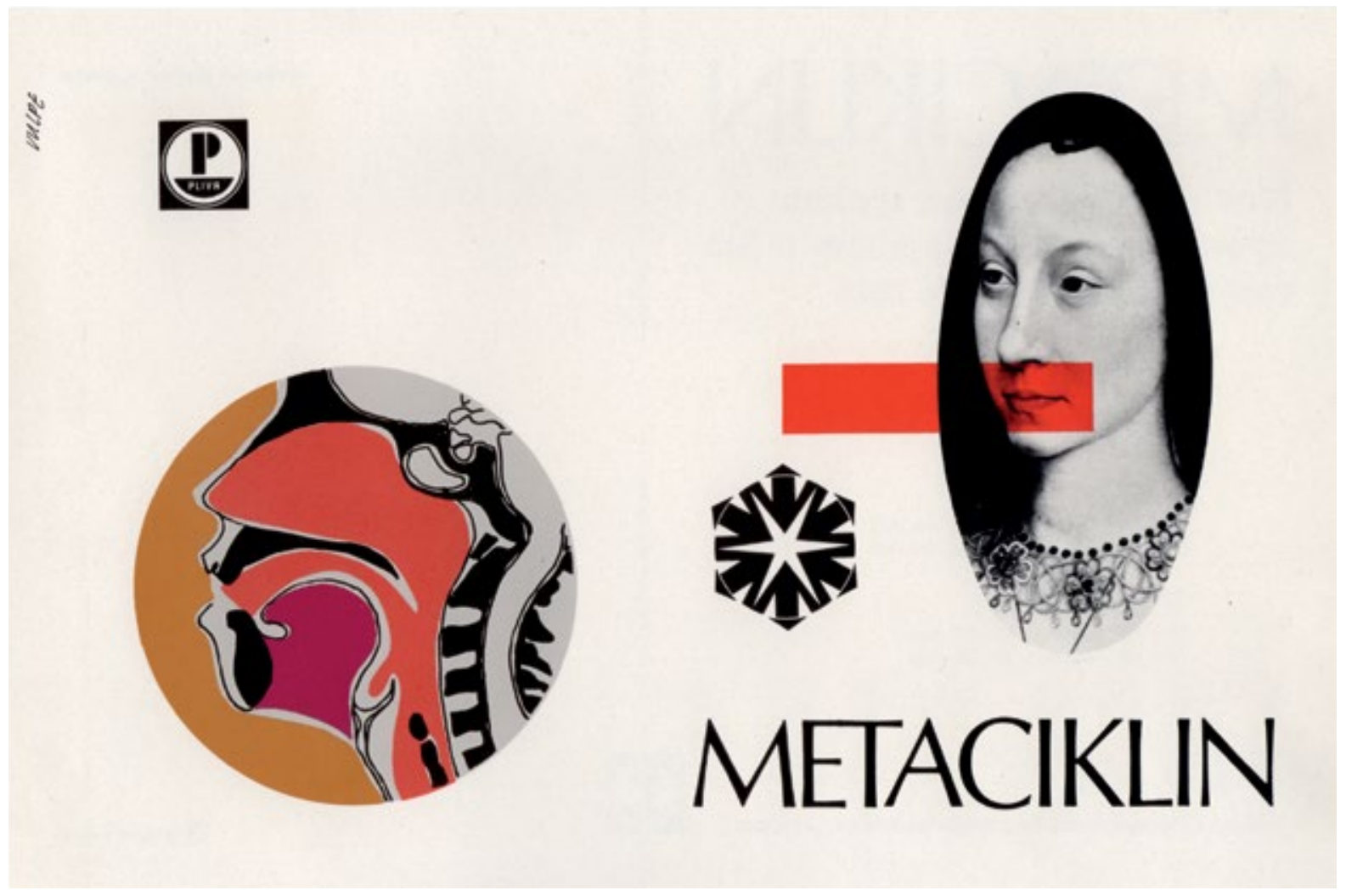

6a Milan Vulpe, deplijan za antibiotik Metaciklin, 1971., MUO

Milan Vulpe, leaflets for antibiotics Metaciklin, 1971 MUO

Za ovaj je postupak zasigurno velikim dijelom zaslužan stereotip o glavoboljama i psihičkim nestabilnostima kao tipičnim ženskim smetnjama. Poznato je kako retorikom oglašavanja dominiraju apeli na rod kao ključni marker identifikacije potrošača, bilo da je riječ o seksualnim fantazijama, bilo definiciji društvenih uloga, moći i statusa. ${ }^{34}$ Nije, stoga, čudno da je Vulpe, kao „produkt svog vremena”, uslijed općeprihvaćene, patrijarhalno nastrojene rodne ikonografije sredine prošlog stoljeća, te suočen s prvenstveno muškom publikom, u promociji ovih lijekova posegao za stereotipnim prikazima psihički slabih i bolesnih žena (sl. 5). Spomenimo i još jednu, iznimno čestu, vrstu motiva u Plivinim promotivnim materijalima koju možemo svrstati pod specifičan tip apela na emocije. Naime, u Plivinim oglasima redovito se pojavljuju motivi čije dekodiranje od čitatelja zahtijeva poznavanje svijeta umjetnosti i visoke kulture.
Naslovnice deplijana za antibiotik Metaciklin citiraju motive iz remek-djela likovne umjetnosti poput Hansa Memlinga (Maria Maddalena Baroncelli, 1470.), Jean-Auguste-Dominiquea Ingresa (Izvor, 1820.), Albrechta Dürera (Adam $i$ Eva, 1507.), Hansa Baldunga Griena (Tri gracije, 1540.). Još su brojniji lijekovi koji su interpretirani u maniri geometrijske apstrakcije (Ceporin, Randolectil, Rimactan, Tussibex, Viomicin), optičke umjetnosti (Nevargal, Penbritin, Chloramphenicol), a česte su i reprodukcije fotografskih eksperimenata kojima je Vulpe ravnopravno oglašavao i Pas+Eutizon (lijek protiv tuberkuloze) i Muzički biennale (sl. 6). S jedne strane, ovu tendenciju možemo pripisati Vulpeovoj (i Plivinoj) manipulaciji specifičnim tipom publike - riječ je o rješenjima očito namijenjenima visokoobrazovanoj eliti, koja pretpostavljenim širokim obrazovanjem laskaju Plivinim klijentima. Na sličan način 

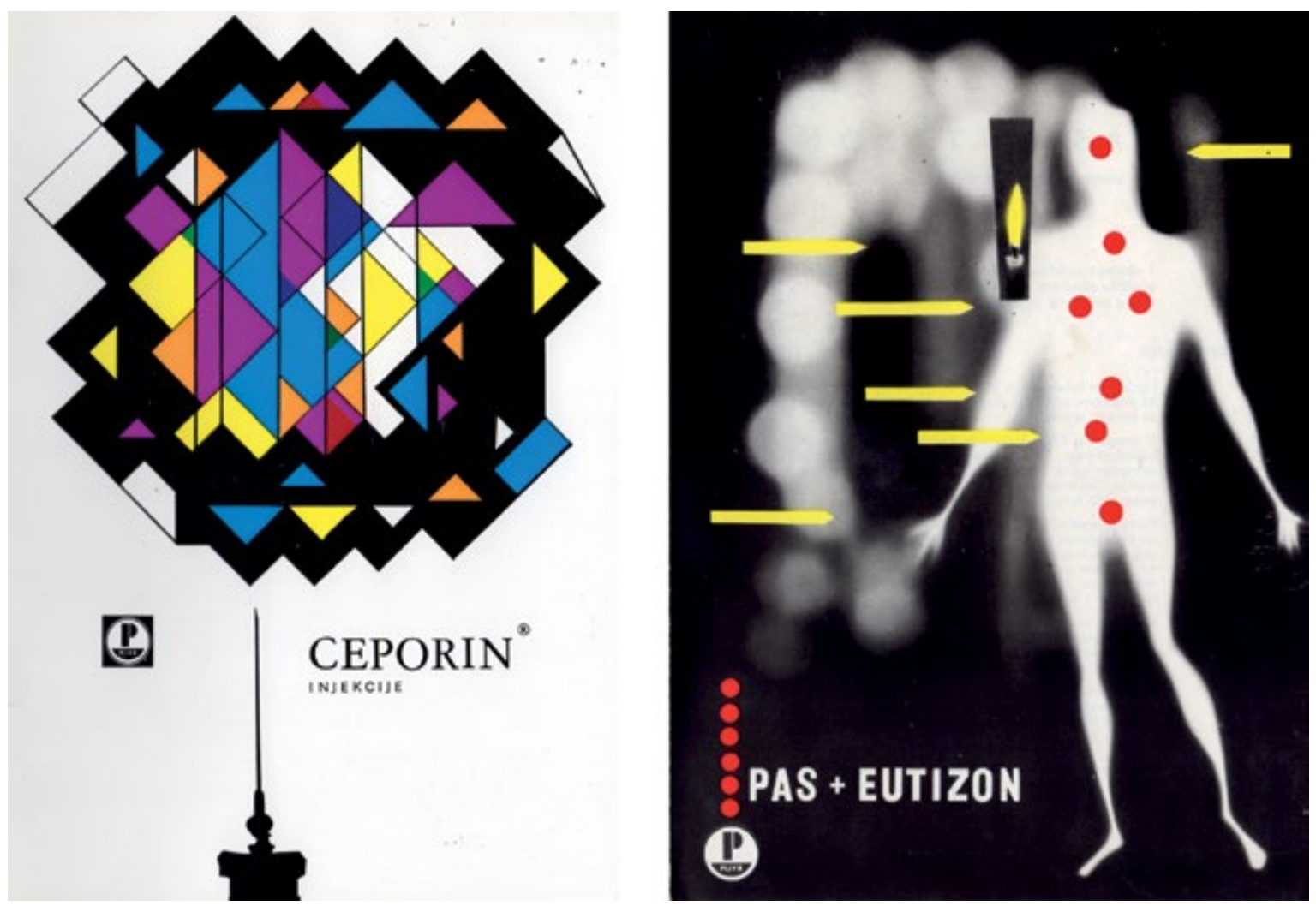

6b Milan Vulpe, deplijani za antibiotik Ceporin, 1972.

i antituberkulotik Pas+Eutizon, 1961., MUO

Milan Vulpe, leaflets for antibiotic Ceporin, 1972,

and antituberculotic Pas+Eutizon, 1961, MUO

Gunther Kress i Theo van Leeuwen ${ }^{35}$ objašnjavaju simboličko čitanje korištenja apstraktnih motiva u raznim komunikacijskim materijalima: „Sposobnost stvaranja i/ili čitanja tekstova utemeljenih na ovoj kodiranoj orijentaciji oznaka je društvene razlike - 'obrazovane osobe' ili 'ozbiljnog umjetnika"”. ${ }^{36} \mathrm{~S}$ druge strane, ne treba zaboraviti da je Vulpeov dizajn nastajao u ozračju exatovskih ideja o sinergiji visoke i popularne kulture, umjetnosti i dizajna. Stoga, odgovor o razlozima za takva rješenja vjerojatno u sebi nosi zrnca obje motivacije, a sasvim je lako moguće da su u odabiru ovakvog pristupa Pliva i Vulpe do cilja došli nošeni različitim porivima.

\section{Racionalni argumenti Plivinih reklama}

Pozivanje na racionalni, znanstveni argument (logos) dominira Vulpeovim rješenjima za Plivu. Takve prikaze prepoznajemo po prisustvu racionalnih, geometrijski preciznih shema i dijagrama, po načinima prikaza ljudskog tijela, po korištenju konvencija tehničkih i znanstvenih prikaza (strelice, isprekidane linije, geometrijski oblici), te po fotografijama i fotogramima medicinske opreme i lijekova (injekcije, tablete, ampule, kapsule). Kress i van Leeuwen uočavaju da naizgled neutralne, objektivne sheme i dijagrami čitatelja postavljaju u poziciju društvene moći: „Pogled odozgo je kut gledanja maksimalne moći. On promišlja svijet iz pozicije božanstva. Svijet nije na dohvat ruke, već pod vašim nogama". ${ }^{37} \mathrm{U}$ tom je smislu posebno indikativan način prikaza ljudskog tijela u Plivinim reklamnim materijalima: kada Vulpe poseže za fotografijama ljudskog tijela, ovi su prikazi gotovo uvijek klinički i impersonalni. Lica su prikrivena ili tek djelomično prikazana sakrivajući identitet, a naglašavajući objektivnost prikaza. Štoviše, najčešće je riječ o 


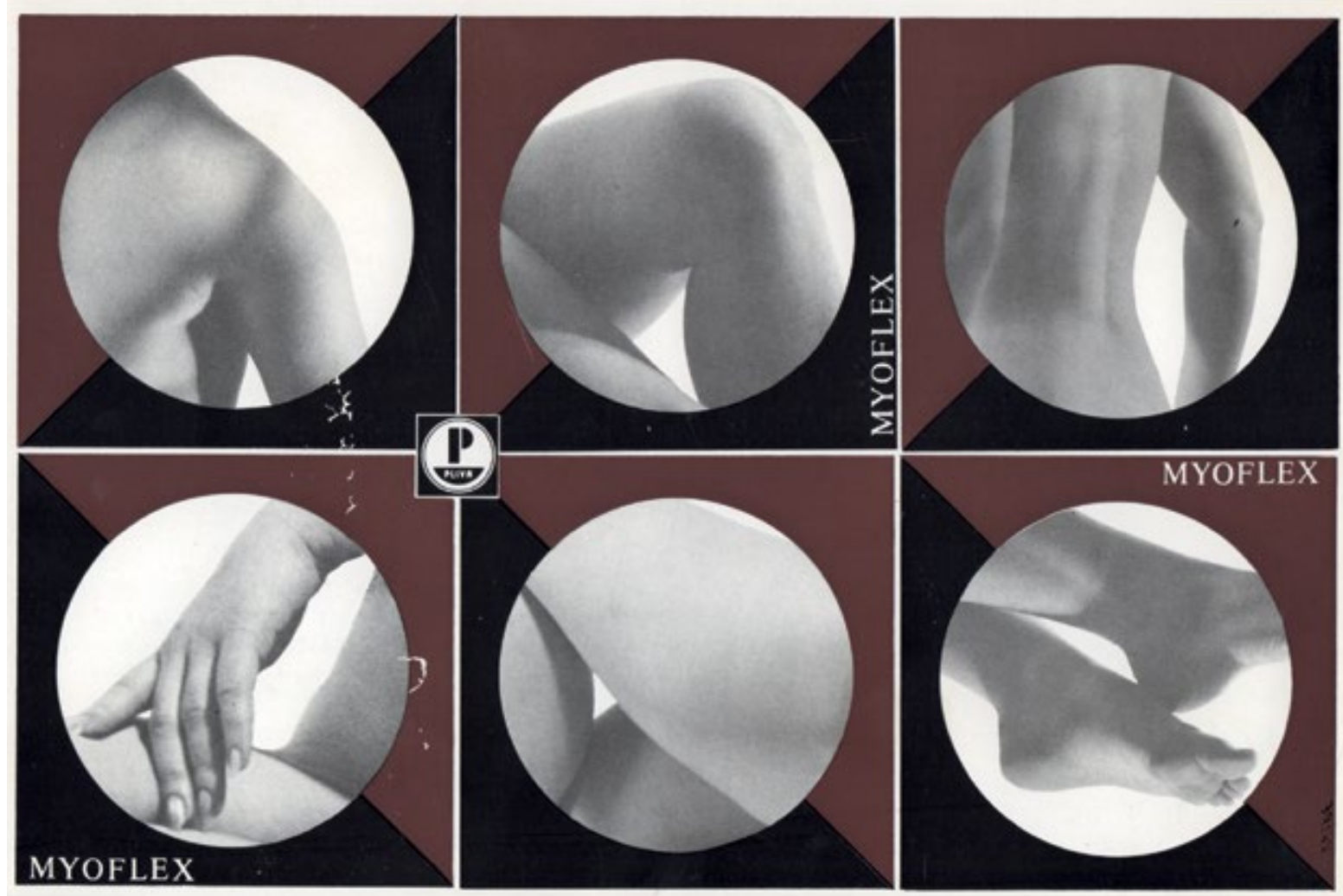

7 Milan Vulpe, deplijan za mišićni relaksans Myoflex, 1971., MUO

Milan Vulpe, leaflet for muscle relaxant Myoflex, 1971 MUO

prikazima izoliranih dijelova tijela (Myoflex, sl. 7), koji su ponekad prekriveni i shematskim crtežima unutrašnjih organa. Takav „rendgenski” pogled Kress i van Leeuwen izdvajaju kao specifičnu varijantu objektivnosti , koja se ne zadržava na vanjskom izgledu već prodire ispod površine $u \mathrm{du}-$ blje, skrivene razine". ${ }^{38}$ Upravo je takva impresija koju Vulpe želi prenijeti čitateljima o njima samima - kao vrhunskim stručnjacima koji posjeduju sposobnost dubinskog sagledavanja problema (i njihovog rješavanja uz pomoć Plivinih lijekova). Specifična publika (ciljna skupina komunikacije) na ponudene argumente reagira na osnovi već usvojenih, specifičnih kulturalnih uvjerenja. Prema Ann C. Tyler, ${ }^{39}$ u dizajnu se strategija uvjeravanja bazira na korištenju već postojećih uvjerenja - nova se uvjerenja uvode kroz predstavljanje općeprihvaćenih vrijednosti čije se karakteristike zatim pripisuju nekoj novoj tvrdnji. Na sličan način i Vulpe gradi odnos sa svojom publikom te unutar dvodimenzionalnog prostora oglasa razvija argument („,Korištenjem Plivinog proizvoda, postajete dio znanstvene elite”), pripisujući kroz niz retoričkih figura i taktika svojoj liječničkoj publici sav neupitni autoritet medicinske i biološke znanosti. Plivini oglasi često zahtijevaju specifična znanja vezana uz medicinsku struku, ne samo određeno predznanje o djelovanju lijeka, već i prepoznavanje konvencija pri interpretaciji jezika shema i dijagrama (Glivenol, Supremin, sl. 8). Drugim riječima, Pliva se kroz Vulpeov dizajn obraća liječnicima njihovim jezikom - jezikom znanosti, medicinskih udžbenika, jezikom enciklopedista i modernizma. Ljudsko tijelo i mehanizmi njegovog funkcioniranja prevedeni su u rječnik mašinskog doba (Lanicor, sl. 9). Mnogi se Vulpeovi deplijani čitaju poput uputa za korištenje u 

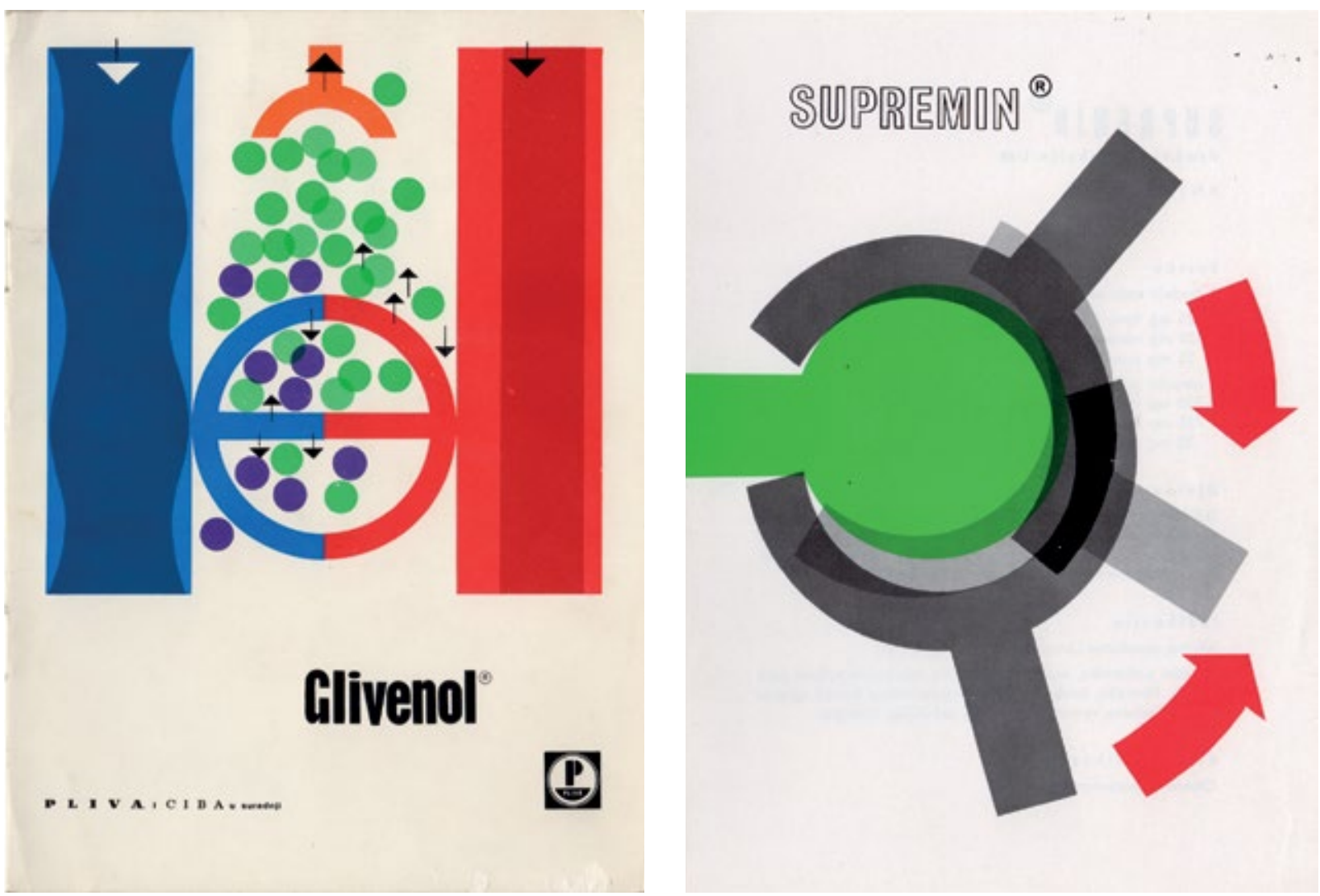

8 Milan Vulpe, deplijani za Glivenol, lijek protiv smetnji venozne cirkulacije, 1969. i antireumatik Supremin, 1967., MUO

Milan Vulpe, leaflet for Glivenol, venotic circulation medicine, 1969, and antireumative Supremin, 1967, MUO

9 Milan Vulpe, deplijan za kardiotonik Lanicor, 1972., MUO

Milan Vulpe, leaflet for cardiotonic Lanicor, 1972, MUO

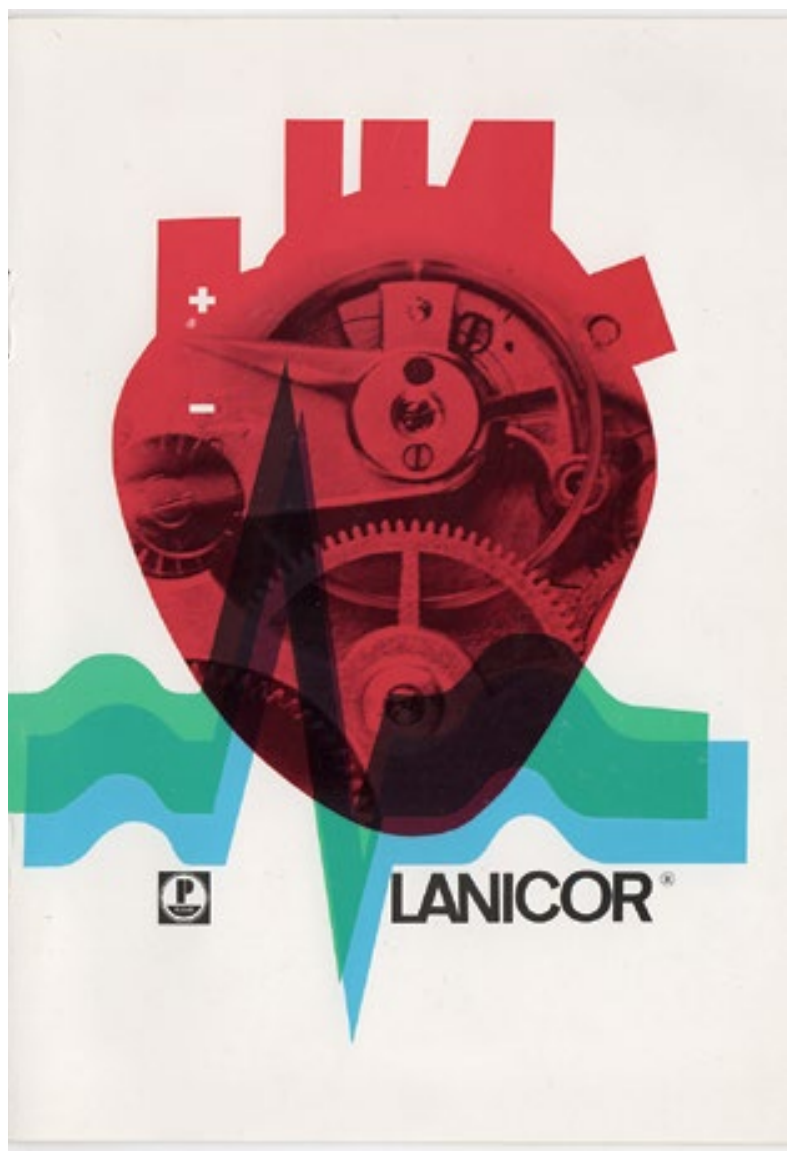




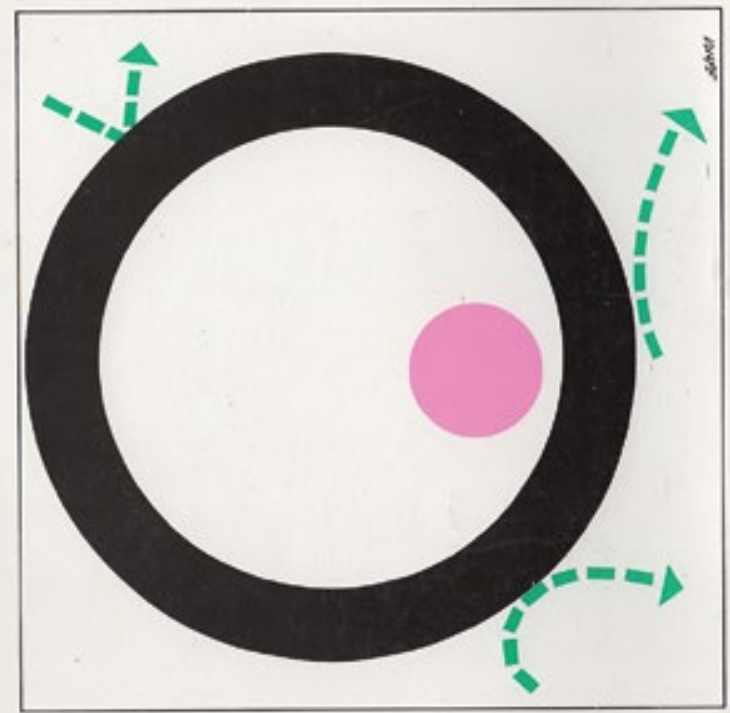

P I I V A

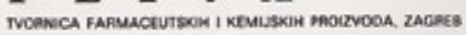

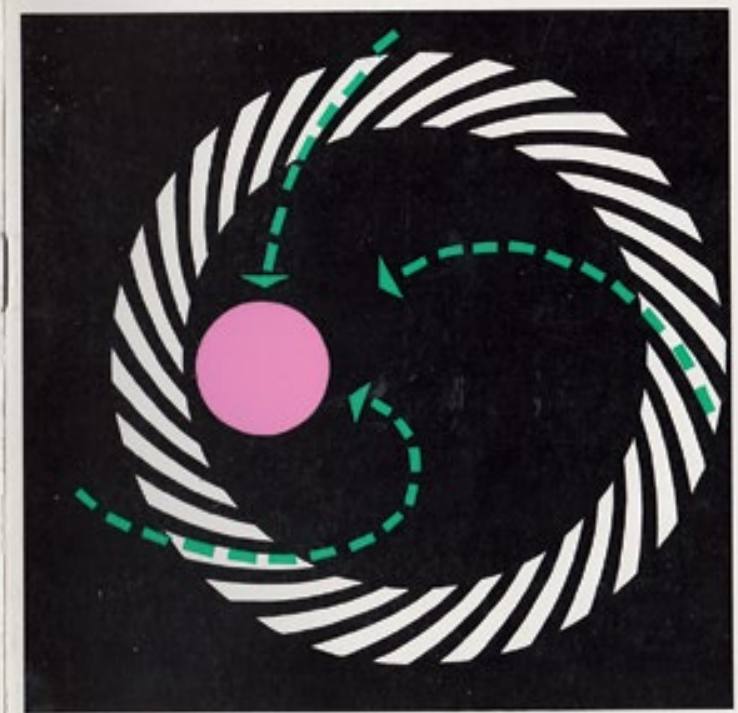

ananase

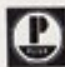

10 Milan Vulpe, deplijan za Ananase (lijek za povećanje propusnosti stijenki žila), 1971., MUO

Milan Vulpe, leaflet for Ananase (medicine to increase vascular wall permeability), 1971, MUO

kojima su geometrijski dijagrami i sheme dodatno obogaćeni strelicama, multiplikacijama i serijama slika koje prikazuju stanje „prije” i „poslije” korištenja lijeka. Vulpe tako često na posljednjoj stranici deplijana ukazuje na medicinski problem dok naslovnica ilustrira djelovanje lijeka (npr. Ananase, lijek koji povećava propusnost stijenki krvnih žila, sl. 10). Charles Kostelnick ${ }^{40}$ u retoričkom čitanju konvencija prikazivanja ljudskog tijela u raznim vrstama praktičnih komunikacija ovakve postupke naziva mikro narativima koji, koristeći konvencije prikaza pokreta, komprimiraju vrijeme i djelovanje, te poput entimema, zahtijevaju retoričko sudjelovanje publike kako bi dovršili njihovo značenje.

\section{Autoritet znanosti}

U Vulpeovom vizualnom leksiku retorici ethosa (pozivanje na autoritet govornika) može se pripisati istaknuto korištenje imena i znakova međunarodnih farmaceutskih korporacija s kojima Pliva surađuje na pojedinim lijekovima (kao znak medunarodno prepoznate pouzdanosti i kvalitete) te posebni obljetnički znakovi dizajnirani za važne Plivine godišnjice poput ,50 godina Plive” ili „,10 godina proizvodnje Geomycina" (kao znak dugogodišnjeg iskustva). Autoritet znanosti posredno se dokazuje i fotografijama i crtežima liječnika i medicinskih sestara pri uporabi Plivinih preparata (Asepsol, Hibitane, sl. 11). Specifičan je primjer ethosa na Plivinim propagandnim materijalima korištenje pravih ili hinjenih mikroskopskih slika koje nisu izravno povezane sa samim lijekom (npr. lijek protiv crijevnih infekcija, Entronon, sl. 12). Iako nevezana uz promovirani lijek, prepoznatljiva vizualnost mikroskopske fotografije ostavlja dojam „znanstvenosti” i istraživačke potkovanosti lijeka. 

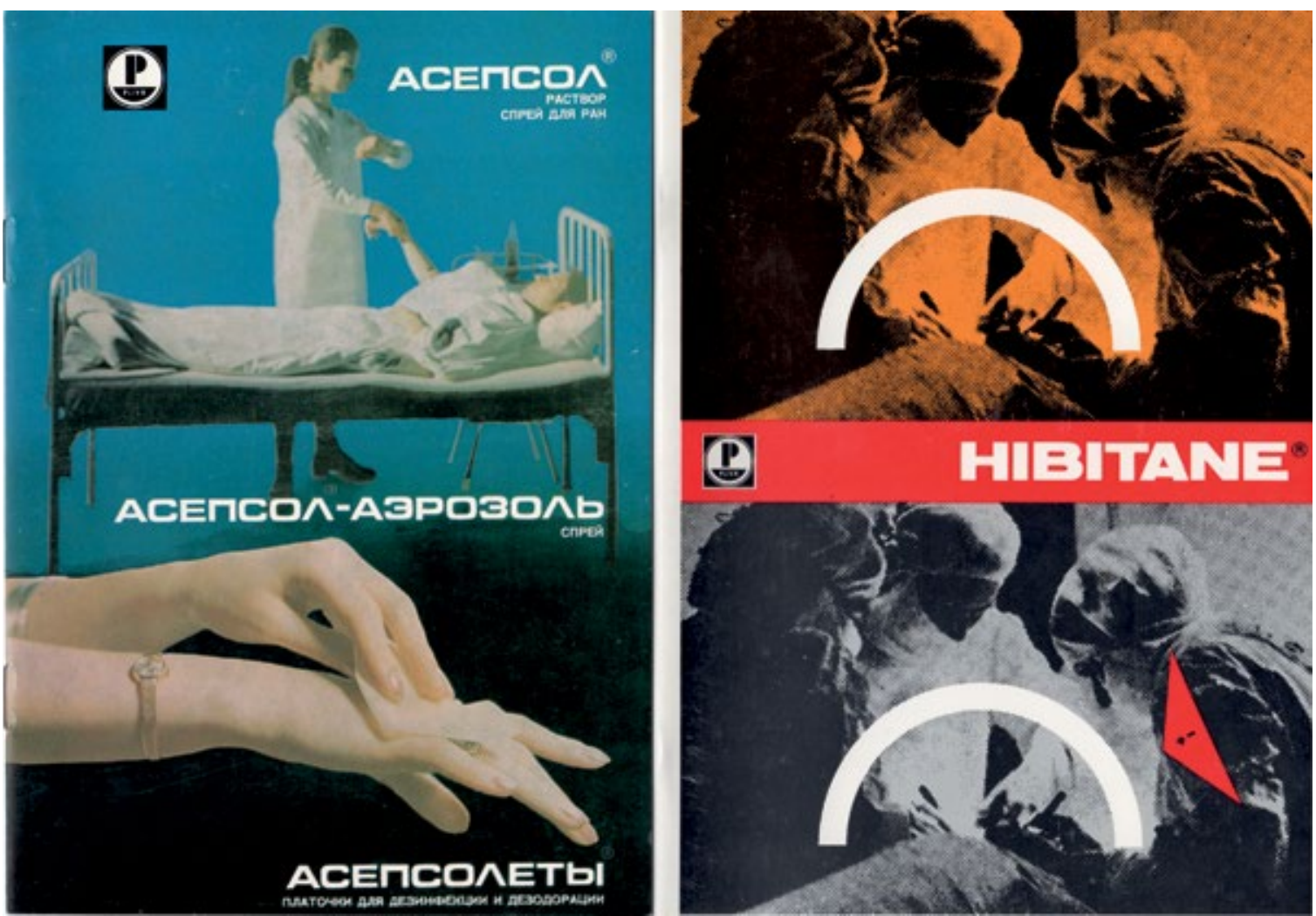

11 Milan Vulpe, deplijani za dezinficijens Asepsol za tržište SSSR, 1970. i antiseptik Hibitane, 1968. - 1970., MUO

Milan Vulpe, leaflet for disinfectant Asepsol for the USSR market, 1970, and antiseptic Hibitane, 1968-1970, MUO

Premda se većina liječničke publike kojoj su deplijani Plive namijenjeni nije bavila istraživačkim radom, uključivanje ovakvih prikaza ne samo da je naglašavalo znanstvenu utemeljenost Plivinih lijekova, već je i samu publiku tretiralo kao člana istraživačkog tima i stvaralo dojam bliskosti s Plivinim znanstvenim istraživanjima. Sličnu je taktiku od 1959. godine primjenjivao američki časopis Science servirajući svojoj publici nevidljiv mikroskopski svijet na naslovnicama časopisa. ${ }^{41}$ Kako navodi Michael Godec, takva je mikroskopska slika služila publici kao prozor u svijet znanosti kroz ,grafički vokabular artikuliran u modernističkom modu vizualizacije”. ${ }^{42}$ Ne treba zaboraviti kako je dvadeseto stoljeće doba znanosti i iznimnih medicinskih dostignuća ujedno i razdoblje u kojem je Pliva uživala velik ugled i izvan jugoslavenskih granica, te stoga pozivanje na autoritet znanosti u oglašavanju Plivinih preparata nije nimalo slučajan.

U razdoblju od 1956. do 1990. godine Milan Vulpe je za Tvornicu Pliva oblikovao izniman broj reklamnih materijala, stvarajući prepoznatljiv vizualni identitet Plivinih lijekova. Pri tome, Vulpe je koristio niz vizualnih taktika $u$ formiranju reklamnih poruka o svrsi i djelovanju Plivinih proizvoda. Retorička analiza Vulpeova dizajna za Plivu otkriva metodički pristup dizajnu vizualnih komunikacija utemeljen na prepoznavanju specifičnosti publike Plivinih proizvoda. Vulpeova suradnja s Plivom govori o klijentu izrazito razvijenog osjećaja za ekonomsku propagandu i razbija predrasude o marketingu u socijalističkom režimu. Istovremeno, ovi nam radovi pružaju specifičan uvid u segment društva kojem se Pliva obraćala, ali i u status znanosti u tadašnjem društvu. Vulpe je iznimno spretno baratao 


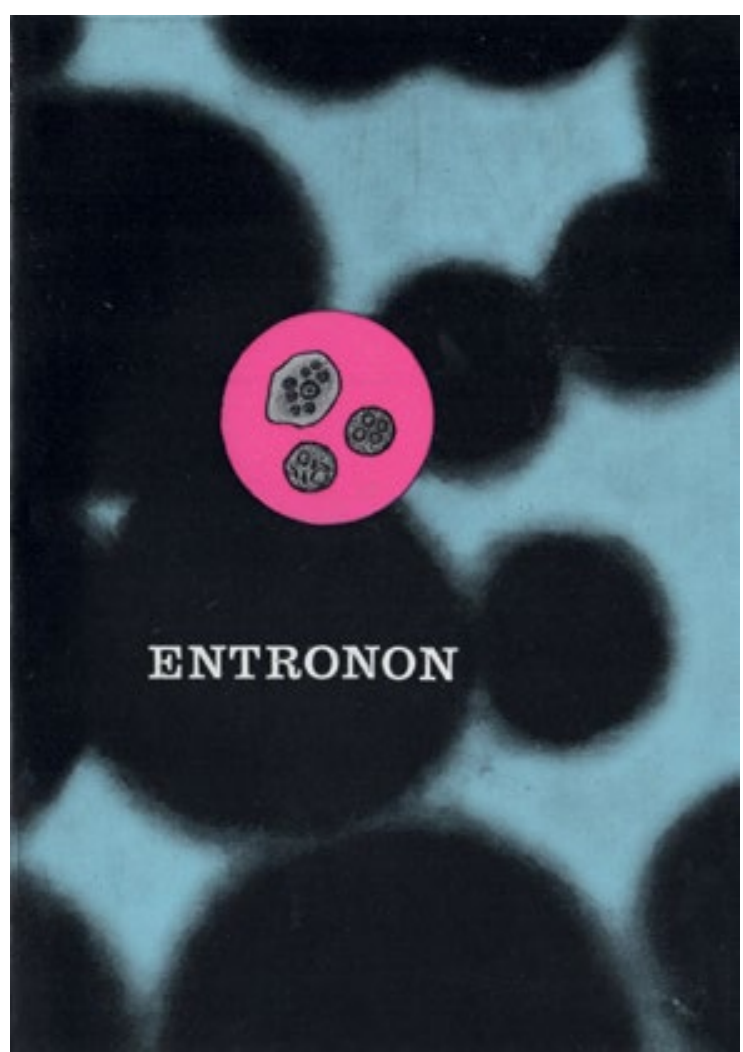

Milan Vulpe, deplijan za Entronon, 1965., MUO

Milan Vulpe, leaflet for Entronon, 1965, MUO

vizualnim rječnikom medicinske struke, suptilno manipulirajući njezinim aspiracijama i ambicijama, dok ju je istovremeno zabavljao, impresionirao i informirao. Analiza načina vizualne aplikacije klasičnih retoričkih apela - pathosa, ethosa, logosa - u Vulpeovim radovima nudi dublje razumijevanje Vulpeova opusa, te društveno-kulturnog konteksta unutar kojeg su ti radovi nastali.

\section{BILJEŠKE}

1 Muzej za umjetnost i obrt (MUO) otkupio je 2014. godine za zbirku grafičkog dizajna Vulpeov dizajnerski opus koji se sastoji od oko 3000 radova (plakata, deplijana, brošura, knjiga, skica) i opsežne arhivske dokumentacije (dokumenti, fotografije, dijapozitivi).

2 Roland Barthes, ,"Rhétorique de l'image,” Communications 4 (1964.): 40-50.

3 Gui Bonsiepe, ,Visual / verbal rhetoric, ” $u$ Looking closer 3, ur. Michael Bierut (New York: Allworth Press, 1999.), 167-173.

4 Gabijela Kišiček, „Vizualna retorika (Istraživanja retorike u 21. stoljeću)", Govor 30 (2013.): 153-169.

5 Na primjer: Sandra Grgić, „Vizualna argumentacija u oglašavanju," diplomski rad (Filozofski fakultet, Zagreb 2016.), te Marijana Petrunić, „Vizualna retorika predizbornih predsjedničkih kampanja,” diplomski rad (Filozofski fakultet, Zagreb, 2018.).

6 G. Mauricio Mejía i Sauman Chu, „A Model for Visual Communication Design: Connecting Theories of Rhetoric, Literacy and Design", The Design Journal 17 (2014.): 29-43.

7 Pokušaji analize dizajna vizualnih komunikacija kroz jednostavnu komparaciju vizualnog jezika s verbalnim retoričkim figurama posebno su česti u suvremenoj teoriji marketinga (Barbara Phillips, Edward F. McQuarrie). Podjednako su česte kritike na takvo „stilističko” pojednostavljenje discipline dizajna (Richard Buchanan, Ann C. Tyler).

8 Jens Kjeldsen analizira klasične retoričke apele logosa, ethosa, pathosa u dizajnu tiskanih oglasa za političke kampanje. Više u: Jens E. Kjeldsen, ,Visualizing Egalitarianism: Political Print Ads in Denmark, "u Communicating Politics, ur. Jesper Strömberg (Göteburg: Nordicom, 2008.)

Richard Buchanan ove apele primjenjuje na širu disciplinu dizajna te kroz njih analizira i industrijske proizvode. Više u: Richard Buchanan, „Design and the New Rhetoric,” Productive Arts in the Philosophy of Culture, Philosophy \& Rhetoric 34, no. 3 (2001.): 183-206. http://www.jstor. org/stable/40238091

9 Jason Tham, „Visual Rhetoric: Parallels and Intersections of Rhetoric and Design Studies," University of Minnesota Digital Conservancy, 2016. http://hdl.handle. net $/ 11299 / 177788$

10 Mejía, „A Model for Visual Communication,” 31.

11 Lada Kavurić, Milan Vulpe: retrospektiva 1945 - 1977, katalog izložbe (Zagreb: 12. zagrebački salon, 1977.), s. p.

12 Tvornica kemijsko-farmaceutskih preparata Kaštel d.d. osnovana je u Karlovcu 1920. godine, a s proizvodnjom započinje 1921. godine. Godine 1928. tvornička postrojenja sele se u Zagreb, na današnju Plivinu lokaciju na Črnomercu. Više o tvornici Kaštel u: Stella Fatović-Ferenčić i Silvija Brkić Midžić, „Početci i strategije marketinga tvornice Kaštel d. d. (1920. - 1945.)”. Medicus 27, 2 (2018.): 211-222. https://hrcak.srce.hr/214617

13 Fatović-Ferenčić i Brkić Midžić, „Tvornica Kaštel,” 217.

14 Ozeha (OZH - Oglasni zavod Hrvatske) započinje s radom 1945. kao politički agitprop, ali ubrzo se transformira u agenciju za ekonomsku propagandu i marketing s podružnicama u Zagrebu, Rijeci, Splitu, Beogradu, Sarajevu i Skopju. Više o radu agencije u: Igor Lah, „Ozeha - O jednoj povijesti oglašivačke industrije,” u Fragmenti dizajnerske povijesti, ur. Marko Golub (Zagreb: Hrvatsko dizajnersko društvo, 2019.), 263-266.

15 Josip Sudar, Ekonomska propaganda u teoriji $i$ praksi (Zagreb: Informator, 1958.).

16 Dušan P. Mrvoš, Propaganda reklama publicitet: teorija i praksa (Zagreb: Ozeha, 1959.). 
17 U Sudarovu priručniku pozitivno je ocijenjena zaštitna figura tvornice Chromos (66), deplijan za Plivin proizvodni program (152), dva deplijana za Chromosove boje (154), te Plivin deplijan za lijek Protamine Zinc Insulin (155). U Mrvoševu priručniku reproducirana su tri Vulpeova rada za Chromos (427).

18 Interpublic je druga najstarija hrvatska poslijeratna oglašivačka agencija, osnovana 1954. godine u Zagrebu.

19 Najraniji primjer suradnje Vulpea i Ozeha dokumentiran u zbirci grafičkog dizajna MUO-a novogodišnja je čestitka za Generalnu direkciju Savezne hemijske industrije (M54373) koju je Vulpe izradio posredstvom agencije Ozeha 1948. godine.

20 Velik broj suvremenih zapadnih oglasa publiciran u oba priručnika dokaz je da su tadašnji propagandni stručnjaci aktivno pratili inozemne marketinške trendove. Također, nekoliko je poglavlja u oba priručnika posvećeno analizi tržišta i potrošača.

21 Kompleksni pojmovi drugi, drugost koriste se u društvenim znanostima (od filozofije, psihologije i sociologije te teorija kulture, feminističkih i postkolonijalnih teorija) u širem rasponu značenja. U ovom tekstu značenje je preuzeto iz teorije socijalnog identiteta, a odnosi se na gradenje identiteta pojedinca kroz pripadnost određenoj društvenoj grupi (ili grupama), te naspram onih (drugih) koji su iz te grupe isključeni (Henri Tajfel).

22 Vida Tomšić, Žena u razvoju socijalističke samoupravne Jugoslavije (Beograd: NIRO Jugoslovenska stvarnost, 1981.), 121.

23 Ukupno gledajući Vulpeov opus za Plivu, unutar oko 700 pregledanih reklamnih oglasa, letaka i brošura na tek 50 primjera uočen je prikaz lika bolesnika/pacijenta.

24 Iako je Pliva ime dobila 1941. godine (Državni zavod za proizvodnju lijekova i vakcina), preteča današnjeg znaka (slovo P iznad valovite površine, $u$ krugu) vjerojatno potječe iz samog početka 1950-ih od kada datira i neonska reklama postavljena na krovu kuće Feller-Stern na Trgu bana Josipa Jelačića. Autor ovog Plivinog znaka nije utvrđen. Prema analizi Plivinih reklamnih materijala, može se utvrditi da se ova prva verzija znaka upotrebljavala do sredine 1957. godine. Izvorna neonska reklama Plive zamijenjena je novijom verzijom 1962. godine. Uz ostale reklamne materijale, Milan Vulpe radio je redizajn osnovnih elemenata Plivinog vizualnog identiteta (memorandumi, poštanske omotnice) 1960-ih, no nije pronađen dokaz da je sudjelovao u redizajnu znaka sredinom 1957 . godine.

25 U promotivnim deplijanima iz 1956. godine tekst o lijeku je opširan i sadrži uvodno poglavlje koje opisuje povijest nastanka lijeka (ili povijest borbe protiv bolesti). Već od 1958. godine tekst više-manje poprima danas uobičajen oblik na uputama za upotrebu lijeka (kratka i činjenična poglavlja o indikacijama, kontraindikacijama, sastojcima lijeka, itd.).

26 Uz ova tri apela, treba spomenuti i kairos koji opisuje kontekst tj. pravodobnost i pravu mjeru argumenta: uspješnost nekog argumenta (ili oglasa) često ovisi o dobro pogodenom trenutku ili okolnostima u kojem je predstavljen publici. Više u: Theresa Enos, Encyclopedia of Rhetoric and Composition: Communication from Ancient Times to the Information Age (New York: Routledge, 2010.), 371.

27 Enos, Encyclopedia of Rhetoric and Composition, 410-416.

28 Enos, Encyclopedia of Rhetoric and Composition, 243-245.

29 Enos, Encyclopedia of Rhetoric and Composition, 492-494.

30 Sudar, Ekonomska propaganda, 79.

31 Steve Sherwood, „Intersections of Wit and Rhetoric: Humor as a Rhetorical Enterprise," Proteus 29, 1 (2013.): 45-52.
32 Od 50 pronađenih prikaza pacijenata, na 40 primjera prikazane su žene.

33 Iako su problemi uzrokovani klimakterijem navedeni kao tek jedna od brojnih (devet) indikacija za propisivanje ovog sedativa, gotovo sve varijante reklama za sedative vežu se uz ženski lik.

34 Diane S. Hope, „Gendered Environments: Gender and the Natural World in the Rhetoric of Advertising," u Defining Visual Rhetorics, ur. Charles Hill, Marguerite Helmers (New Jersey: Lawrence Erlbaum Associates, 2004.), 155178.

35 Gunther Kress i Theo van Leeuwen, Reading Images: the Grammar of Visual Design (London, New York: Routledge, 2006.)

36 Kress i Leeuwen, Reading Images, 165.

37 Kress i Leeuwen, 145.

38 Kress i Leeuwen, 145.

39 Ann C. Tyler, ,Shaping Belief: The Role of Audience in Visual Communication,” Design Studies 9, 1(1992.): 21-29.

40 Charles Kostelnick, Humanizing Visual Design: The Rhetoric of Human Forms in Practical Communication (London, New York: Routledge, 2019.), 124-127.

41 Michael Godec, „Visual style and forms of Science in the Cold War," u Visual Rhetoric and the Eloquence of Design, ur. Leslie Atzmon (Anderson: Parlor Press, 2011.), 1-27.

42 Godec, „Visual style and forms,” 17. 


\section{REFERENCES}

Barthes, Roland. "Rhétorique de l'image." Communications 4 (1964): 40-50.

Bonsiepe, Guy. "Visual / verbal rhetoric." In Looking closer 3. Edited by Michael Bierut, 167-173. New York: Allworth Press, 1999.

Buchanan, Richard. "Design and the New Rhetoric." Productive Arts in the Philosophy of Culture, Philosophy \& Rhetoric 34, no. 3(2001): 183-206. http://www.jstor.org/ stable/40238091

Enos, Theresa. Encyclopedia of Rhetoric and Composition: Communication from Ancient Times to the Information Age. New York: Routledge, 2010.

Fatović-Ferenčić, Stella and Silvija Brkić Midžić. "Početci i strategije marketinga tvornice Kaštel d. d. (1920.-1945.)."Medicus 27, 2(2018): 211-222. https:// hrcak.srce.hr/214617

Godec, Michael. "Visual style and forms of Science in the Cold War." In Visual Rhetoric and the Eloquence of Design. Edited by Leslie Atzmon, 1-27. Anderson: Parlor Press, 2011.

Grgić, Sandra. "Vizualna argumentacija u oglašavanju." Graduate thesis, University of Zag'reb, 2016. http://darhiv. ffzg.unizg.hr/id/eprint/7528

Hope, Diane S. "Gendered Environments: Gender and the Natural World in the Rhetoric of Advertising" In Defining Visual Rhetorics. Edited by Charles Hill, Marguerite Helmers, 155-178. New Jersey: Lawrence Erlbaum Associates, 2004

Kavurić, Lada. Milan Vulpe retrospektiva 1945 1977. Exhibition catalogue, Zagreb: 12. zagrebački salon 1977.

Kišiček, Gabrijela. "Vizualna retorika (Istraživanja retorike u 21. stoljeću)."Govor 30 (2013): 153-169. https://hrcak.srce. $\mathrm{hr} / 166020$

Kjeldsen, Jens E. "Visualizing Egalitarianism: Political Print Ads in Denmark." In Communicating Politics. Edited by Jesper Strömberg, 139-160. Göteburg: Nordicom, 2008.

Kostelnick, Charles. Humanizing Visual Design: The Rhetoric of Human Forms in Practical Communication. London, New York: Routledge, 2019.

Kress, Gunther and Theo van Leeuwen. Reading Images the Grammar of Visual Design. London, New York: Routledge, 2006.

Lah, Igor. "Ozeha - 0 jednoj povijesti oglašivačke industrije." In Fragmenti dizajnerske povijesti. Edited by Marko Golub, 263-266. Zagreb: Hrvatsko dizajnersko društvo, 2019.

Mejía, G. Mauricio, Sauman Chu. "A Model for Visual Communication Design: Connecting Theories of Rhetoric, Literacy and Design." The Design Journal 17 (2014): 29-43.

Mrvoš, Dušan P. Propaganda reklama publicitet teorija i praksa. Zagreb: Ozeha, 1959.

Petrunić, Marijana. "Vizualna retorika predizbornih predsjedničkih kampanja." Graduate thesis, University of Zagreb, 2018. http://darhiv.ffzg.unizg.hr/id/eprint/11012/

Tham, Jason. "Visual Rhetoric: Parallels and Intersections of Rhetoric and Design Studies." University of Minnesota Digital Conservancy, 2016. http://hdl.handle. net/11299/177788

Sherwood, Steve. "Intersections of Wit and Rhetoric: Humor as a Rhetorical Enterprise." Proteus, 29, 1 (2013): 45-52

Sudar, Josip. Ekonomska propaganda u teoriji i praksi. Zagreb: Informator, 1958.

Tomšić, Vida. Žena u razvoju socijalističke samoupravne Jugoslavije. Beograd: NIRO Jugoslovenska stvarnost, 1981.

Tyler, Ann C. "Shaping Belief: The Role of Audience in Visual Communication." Design Studies, 9, 1(1992): 21-29. 


\title{
SUMMARY
}

\section{Milan Vulpe's Visual Codes: the Rhetoric of Pliva's Advertisements from 1956 to 1990}

\begin{abstract}
In 2014, the Museum of Arts and Crafts in Zagreb purchased about 3,000 items for the collection of graphic design as well as rich archival documentation of the Croatian designer Milan Vulpe (Dubrovnik, 1918 - Zagreb, 1990). Vulpe realized the most of his works in the field of advertising design for Croatian companies, institutions and cultural and economic events. He worked for the Pliva pharmaceutical and chemical products factory in the period from 1956 to 1990. During this collaboration, he designed, among many other elements of visual communication, about a thousand promotional leaflets and brochures for Pliva's medicines and drug preparations. Based on the preserved works and archival documentation, the article analyzes for the first time Vulpe's tactics in communicating Pliva's medicines through the vision of visual rhetoric as an analytical method focused on visual persuasion procedures. Through the application of the postulates of classical rhetorical canons, Pliva's advertising activity and Vulpe's and Pliva's progressive efforts in building relationships with the target audience are analyzed. A rhetorical analysis of his design for Pliva reveals a methodical approach to the design of visual communications based on recognizing the specifics of the audience of Pliva's products. This communication process is not just about intuitively finding a common language between a talented designer and the medical profession, but about a thoughtful and constructed approach to Pliva's audience, designed on the basis of the then accepted postulates of economic propaganda. Vulpe's collaboration with Pliva speaks to the client's highly developed sense of economic propaganda and breaks down prejudices about marketing under the socialist regime.
\end{abstract}

KORALJKA VLAJO (Zagreb, 1971.) voditeljica je zbirki grafičkog i produkt dizajna Muzeja za umjetnost i obrt. Autorica je više izložbi, među njima: Porculanski sjaj socijalizma, Marijina industrija ljepote, Skriveni dizajn, te izložbe In a Nutshell o suvremenom hrvatskom dizajnu. Koautorica je izložbi Dizajn za novi svijet u beogradskom $\mathrm{Mu}-$ zeju Jugoslavije, te Davor Grünwald: industrijski dizajn u kontekstu tehnologije u Tehničkom muzeju Nikola Tesla u Zagrebu.
KORALJKA VLAJO (Zagreb, 1971) is the head of the graphic and product design collections of the Museum of Arts and Crafts in Zagreb. She is the author of several exhibitions, among them: Porcelain Gleam of Socialism, Marija's Industry of Beauty, Hidden Design, and the In a Nutshell exhibition on contemporary Croatian design. She co-authored the exhibition Design for a New World at the Belgrade Museum of Yugoslavia, and Davor Gr ünwald: Industrial Design in the Context of Technology at the Nikola Tesla Technical Museum in Zagreb. 